\title{
The Authority of Ulama and the Problem of Anti-State Militancy in Pakistan
}

\author{
Muhammad Akram \\ International Islamic University Islamabad, Pakistan
}

\begin{abstract}
Pakistan's religious leaders, ulama, have been put under significant strain in relation to how deal with questions about the political tensions and violence over the past decade flowing from the Taliban's role in conflict in Afghanistan and Pakistan. The effects of this fraught environment on religious authority can be seen through the way that religious leaders have issued contradictory and opaque fatwa (non-binding, but highly influential, legal opinions). This article particularly considers the way that different fatwa-giving religious groups, such as Deobandis, Brevalis, and Ahl-i-Hadith, have dealt with these problems. The violence, which has struck the heart of Pakistan civil society, has led to a confusing array of fatwa from these religious elites. These opinions have sought to categorize violence as either legitimate or to be condemned. This article therefore shows how these fatwa and the conflicting positions they taken have compromised religious authority in contemporary Pakistan.
\end{abstract}

\section{Keywords}

Islam - authority - politics - Pakistan - fatwa

Pakistan's recent history has been marked by both ideological strife and communal violence. These conditions - shaped in powerful ways by geo-political forces, as well as by more local dynamics - have both reflected and further amplified a dramatic fragmentation of religious authority in the country. Ethnic violence in Karachi, a separatist movement in the province of Baluchistan, and religiously motivated anti-state militant activities have destabilised the entire nation. One particularly severe site of violent contact has been the semiautonomous tribal region situated along the Afghan border in the north-west 
part of the country. There, groups often grouped under the broader rubric of "Taliban" operate independently from each other, pursuing different objectives, while sharing aspects of a wider religious and ideological orientation. Most of these groups are affiliated to an umbrella organisation called Tehrik-e-Taliban Pakistan (TTP). ${ }^{1}$ This article critically examines the impact that these groups have had on recent reconfigurations of Muslim religious authority in Pakistan.

At least three patterns are discernible in the organisation and activities of such groups. First, they are active in military operations in the historically unruly tribal areas along the border between Pakistan and Afghanistan. These groups directly challenge the government in these remote and rugged borderlands. Secondly, they undertake sporadic attacks throughout the country that target the military, paramilitary, police forces and sometimes also civilians whom they perceive as loyal to the Pakistani state. Often, the violence comes in the form of suicide attacks, for which the Taliban publicly accept responsibility. Thirdly, there are occasional bomb blasts in urban civic centres for which no-one usually claims responsibility, but for which it is alleged that the Taliban are responsible. The Taliban have, on occasion, publicly denied their involvement in this type of incidents. The conflict has seen 35,60o Pakistanis-most of which were innocent civilians-lose their lives between 2004 and 2010 (Crawford, 2011; Rana, 2009, 2010, 2011). There has been a decrease in the number of incidents of violence and terrorist attacks, as well as the number of fatalities, reported in subsequent years. Yet, despite this reduction, tragedies continuewith 2,050 deaths as a result of terrorist attacks in 2012 (Rana, 2013: 7).

Religious leaders from more "mainstream" Islamic groups, including the Deobandis $^{2}$ and Barelwis ${ }^{3}$ have issued numerous fatwas to denounce and condemn terrorist attacks, especially those targeting civilians. The question

1 The term "Talibanisation" has been used disapprovingly by people to refer to the process of gradual disruption of the existing social and political institutions by these groups, who then impose their narrow and totalitarian understanding of Shari'a in the areas under their control (Mir, 2009).

2 The term "Deobandi" is used for the reformist Sunni movement in South Asia inspired by the teachings promulgated by elders (akabirs) of the madrasa, Dar al-'Ulum Deoband. The madrasa was established in 1866 in Deoband, India. The movement has a wide following across the region. For further reading on the madrasa of Deoband and its founders, see Metcalf (1982).

3 The term "Barelwi" refers to a South Asian Islamic movement, which was founded by Ahmed Raza Khan (1856-1921) of Bareilly, India. The movement is based on Sufi practices, shrine culture and celebrates wholehearted love for the Prophet Muhammad. The movement claims to have the largest following within the Sunni Muslim community of Pakistan. For further discussion of this movement and its founder, see Sanyal (2005). 
remains, however, as to how authoritative such fatwas are and for whom. This question is important when bearing in mind the contention of scholars, like Muhammad Qasim Zaman, in that ulama in South Asia have found new ways to construct and assert their traditional authority in the face of modern socio-political developments (Zaman, 2002). This situation of on-going religious responses to political and social change is nothing new in South Asia. Francis Robinson has noted that the reformation of Islamic knowledge and practice has been occurring since the earliest periods of the Muslim community. The "modernist" Deobandi were one of the most influential movements for Muslim reform in the region. It is now these firmly-entrenched Deobandi religious figures and their organisations whom are being challenged by a new breed of actors, many of whom may well have been their students and are now willing to act forcefully and violently to implement their own extreme interpretations of Islamic teachings (and political ideology) (Robinson, 2008). These religious leaders are caught not just between different interpretations of Islamic doctrine, but also in political forces beyond their control. In negotiating this extremely different religious and political landscape, the reactions to acts of violence can become sties of considerable contestation between ulama affiliated with different communities (Zaman, 2012: 297).

In this context, ulama associated with the Taliban often set themselves in opposition and sometimes in violent conflict with mainstream Islamic groups with whom they do not agree (Alam, 2008). This situation gives rise to the question of the extent to which the Taliban and the persistence of anti-state militancy that ulama associated with more established communities such as the Deobandis and the Barelwis have lost, at least part, of their juristic, traditional and charismatic authority.

\section{Militancy and Conflict}

To understand the changing configurations of Muslim religious authority in contemporary Pakistan, it is necessary to understand the socially- and politically-contentious environment in which they now operate. The Afghan Taliban enjoyed good relations with the Pakistani state before the terrorist attacks of 11 September 2001. Before that, Pakistan had been one of the only three countries that had recognised the Taliban government of Afghanistan. Even today, not all groups associated with the Taliban are fighting against the Pakistani state and there are a few groups, including the so-called Haqqani network whose primary purpose is to resist the presence of foreign forces in Afghanistan. 
A large part of the problem of anti-state militancy is an outcome of Pakistan's decision to support the us-led war against the Taliban and al-Qaeda in Afghanistan. Pakistan did not send any troops into Afghanistan, but provided crucial intelligence and logistics support for us operations. After the fall of Taliban in Afghanistan, scores of fighters escaped to the semi-autonomous and tribal areas of Pakistan, where they already had strong ethnic and ideological connections. In 2004, the Pakistan military launched its first major military operation in these border areas to eliminate sanctuaries of Taliban and al-Qaeda fighters.

Initially, these clashes were limited in scale and confined to the distant border regions. However, in 2006, a missile strike on a madrasa near the Afghan border in Bajaur district, which killed 83 civilians most of whom were children proved to be a turning point. The government of Pakistan accepted responsibility for this incident claiming that the madrasa was a base for terrorists. However, the Pakistani media reported that it was an American missile that was fired from a drone. The ambiguous nature of the causes of this event heightened tensions even further. Within a few days, the first suicide attack outside the tribal areas took place on a Pakistan army facility in Dargai, Malakand. This attack led to 45 army recruits being killed and 20 others wounded.

A year later, another incident occurred that proved to be a major turning point in religiously motivated anti-state militancy in Pakistan. Right in the heart of the capital Islamabad, the clerics at one of the central mosques of the city, known as the Red Mosque, entered into a standoff with government authorities. As a result of this impasse, a contingent of Pakistan Army commandos from the Special Services Group (SSG) stormed the Red Mosque complex. The complex was destroyed and many died, including female students, who perished as they were trapped in the complex and believed to have been caught up in the cross-fire during the operation. ${ }^{4}$ This incident in turn triggered a series of bomb blasts in public areas and brutal attacks on government and armed forces installations.

4 Sources have conflicting accounts of the number of casualties in the operation. The government sources suggest up to 100 fatalities. However, the Red Mosque Imam claimed that 1,00o female students had been killed during the operation. See Iqbal (2013) and Hasan (2013). 


\section{Initial Responses of the Pakistani Ulama}

In the religious newspapers, magazines and official publications of important madrasa (religious seminaries) of Pakistan published after the October 2011 start of the us-led war in Afghanistan, there was a solid consensus of ulama asserting that Western powers were unjustly invading a Muslim country. Many ulama did condemn the terrorist attacks on the Twin Towers in New York and other American targets saying that the Islamic Shari'a rejects the killing of innocent civilians even in the event of war. However, many of them also argued that there was not sufficient evidence presented by the Americans to prove the involvement of Osama bin Laden or al-Qaeda in these attacks. For instance, an important Barelwi monthly magazine, Ziya-e-Haram, published a fatwa in December 2001 on this topic, stating that:

Muslims should unanimously refute allegations levelled against them by the United States of America [...] the U.s. should present solid proof against Osama bin Laden. Osama and Afghanistan deserve our sympathy and support for being our neighbours and for being Muslims. The Pakistani government should stand firm against the U.s. and her unjustified intervention. It is the responsibility of the Pakistani government to declare jihad. If, in spite of the pressure of public and ulama, the Pakistani government provides bases to the U.S. and, as a result of that, the general public and some organisations have become frustrated and if they directly attack American facilities or their airplanes it would be permissible. However, doing so would not be an imperative or obligatory for the people.

Ziya-e-Haram, 2001: 64-66

This fatwa is unequivocally against the us-led war against the Taliban government in Afghanistan and warns against Pakistani cooperation in the invasion. It permits ordinary people or private organisations to attack American facilities or equipment inside Pakistan, but does not take into account the possibility that such uncontrolled reactions could spin out of control and turn against the Pakistani forces themselves, which consequently happened.

Around the same time, the Jami'a Dar al-'Ulum Karachi, one of the most influential Deobandi seminaries in Pakistan issued an important joint statement from its ulama on the same subject:

Muslims feel sympathy for the American people who have been made victim of this terrorism unjustly. And the American anger is understandable to this extent. However, it is against the established principles of justice 
that without reflecting on the real causes behind this tragic incident and without any proof, the U.s. has straight away singled out an individual to blame and has started threatening to invade Afghanistan [...] on this occasion, we are aware of the sensitive situation which the government of Pakistan is faced with, and its announcement of cooperation with the international community against terrorism is right too. However, before taking any practical steps, it is imperative that it creates limits for legitimate and reasonable cooperation. It is by no means lawful for the [Pakistani] government to facilitate any military action that is meant to punish an individual without any proof or for the covert purpose of invading a Muslim country and destroying it on this pretext.

AL-BALAGH, 2001: 29-30

This earlier statement is similar to the one published in Ziya-e-Haram; however, it seems to be more sensible and carefully formulated. It does not incite the government of Pakistan to declare jihad against the us, nor does it grant license to the general public to undertake attacks against American interests inside the country. We shall discuss below, how and why the perspectives diverged so dramatically over the years that followed.

The Pakistani ulama denounced the terrorist attacks of 11 September in unison, just as they later also condemned the London bombing of 7 July 2005 (al-Balagh, 2005). However, they did not endorse the response of America and their allies to these tragic events. One major concern of the ulama has been the definition of terrorism. To begin with, an important authority of the Deobandis is Muhammad Taqi Uthmani from Karachi who discussed the definitional problem of who should be categorised as an "extremist" and "terrorist". He maintained that Western powers have coined these ill-defined terms to refer to any Muslims who refuse to submit to their hegemony (Usmani, 2001: 525). Later, another central political and religious figure of Deobandis, Sami' al-Haqq of Jami'ah Haqaniyyah, Akora Khattak, complained in an interview with a Norwegian journalist that even those who are fighting for freedom against oppressors are called "terrorists" by the Western world (Haqqani, 2005). Among other important religious scholars who raised the issue of the definition of terrorism is Javed Ahmad Ghamidi, who is known for his moderate and accommodative approach. On 28 October 2001, he published in the daily Urdu newspaper Pakistan, a definition of terrorism as: "Undeclared aggression against the life, property or honour of non-combatants is terrorism." A serious debate took place over this definition in the subsequent issues of the monthly Ishraq magazine, which is published from Lahore (Ahmad, 2002; Hasan, 2002). The rationale for discussing the issue of definition was that during this period Pakistani society 
in general and the ulama community in particular had serious apprehension about the term "terrorism" and how it could be used as an instrument of propaganda against Muslims who many believed were engaged in legitimate wars of liberation from the occupation of non-Muslims. In this way, Pakistanis were particularly concerned about the status of the armed struggle of Kashmiri Muslims against Indian occupation.

Immediately after the fall of Taliban regime in Afghanistan, the Pakistan army began raising its troop levels along the Pakistan-Afghanistan border to prevent the influx of militants or to capture them, especially those belonging to al-Qaeda. The first major Pakistani army operation of this type took place in Wana, South Waziristan, in 2004. On that occasion, many Pakistani ulama expressed their disapproval of this operation through a variety of channels. Over 500 ulama, most of them Deobandi, issued a fatwa declaring that the operation was against the teachings of Sharica:

In the present scenario, it is totally unlawful, forbidden, and a matter of grave sin for the Pakistani army to take action in Wana (Waziristan) against mujahidin [those who wage jihad] or their Muslim supporters, to kill them or help in their killings under the pretext of fighting against terrorism. For any such action would be against the clear injunctions of the Qur'an and Sunnah, no matter if such action is taken under the intense pressure of the U.s. or otherwise [...] if a soldier obeys the orders of his commanders or political leaders that are against the Shari'a, he would be committing a grave sin, and if in the course of action he gets killed by no means would he be called a shahid [a honorific title for martyrs in the cause of Islam].

AL-DAYYAN, 2004: 2

This fatwa was disseminated on the Internet carrying the names of the ulama endorsing it with their signatures and official seals affixed. The fatwa has also been referred to in a pro-Taliban booklet titled Jihad-e-Pakistan, which is available online (Masud, 2001). The language of this fatwa is unambiguous in denouncing the Pakistan army's operation against militants in tribal areas. Two other points are worth noticing here. First, signatories on the fatwa include some of the most important religious leaders associated with influential seminaries like Jamíah Banauri Town (Karachi), Jami'ah Ashrafiyya (Lahore), Dar al-'Ulum Talim al-Qur'an (Rawalpindi), Jami'ah Imdadiyya (Faisalabad) and the Dar al-'Ulum Haqqaniyyah Akora Khattak (Nowshera). Second, all the signatories are associated with Deoband, although the names of some of the most prominent Deobandi muftis and their seminaries—-for instance, Mufti 
Muhammad Taqi Usmani and Mufti Rafi Usmani of Dar al-'Ulum Karachiwere missing. This probably indicates a greater support for the Taliban by some Deobandi ulama who also share a common Pashtun ethnicity with the Afghani Taliban.

Generally speaking, the positions of ulama toward the Taliban in the early period of the Pakistan military operations in Waziristan were conditioned by four major factors. First, many of the ulama categorically opposed the us-led invasion of Afghanistan and for that matter against any practical Pakistani cooperation with the us and her allies in this war. Second, when the Pakistan army launched its first major operation in the tribal areas, the sympathies of a significant group of ulama were with the militants, instead of the army. Third, terms like "terrorism" and "extremism" were problematised in the discourses of the ulama. Instead, they preferred to use the classical jurisprudential terminology and conceptual frameworks of figh in order to construct and articulate their perspectives and provide legitimacy, or otherwise, of certain actions. Fourth, clear differences of opinion between adherents of different Muslim groups had not yet appeared, although a more forceful pro-Taliban stance among the Deobandi ulama was clearly beginning to emerge at the time.

\section{Divergence Develops among Ulama}

As the Pakistan military campaign dragged on, the sphere of operations against militants increased and their activities started to extend to the urban centres of the country and, as a consequence, the general sympathy for the Taliban in Pakistani society diminished. This was fuelled in part by intra-Muslim communitarian dynamics. In 2005, a prominent Barelwi cleric, Munib al-Rahman, issued a fatwa against terrorism and suicide attacks specifically in Pakistan. He got his fatwa approved by $5^{8}$ eminent ulama of different religious factions, including Deobandis, Ahl-i-Hadith and Shicis. ${ }^{5}$ This fatwa is relatively brief and comprises just three pages. It focuses on the question of killing innocent civilians during terrorist attacks. The fatwa proclaims:

5 The Ahl-i-Hadith is a modernist Islamic movement that arose in the 19th century in India and argued for direct guidance from the Qur'an and Hadith. It denied the widely-accepted interpretive authority of the established schools jurisprudence ( figh). Today the movement is a relatively small faction of Sunni Islam in the Indian subcontinent. For further reading, see Brown (1999: 27-32). 
Carrying out suicidal attacks, bomb blasts, and killing of innocent Muslims by firing sprees in mosques or public meetings, and considering these acts jihad is unlawful [haram], and to do so with religious conviction and expectation of reward (in the hereafter) is infidelity [kufr]. However, if someone kills a Muslim or non-Muslim citizen for being overwhelmed by anger or enmity or some other psychological reason, it would be a matter of grave sin [though not infidelity].

AL-RAHMAN, 2005

The fatwa is toned down at the end by asserting that this judgment applies only in the context of Muslim societies like Pakistan. It closes with a note stating that while in other contexts where Muslims are engaged in legitimate struggle against foreign occupation forces a different ruling may be applicable.

By 2007, after the episode of the Red Mosque in Islamabad and the uncompromising attitude of its clerics, who were considered to be quite close to the Taliban, many in Pakistan grew increasingly critical of the perceived "Talibanisation" of the country. In order to understand the Red Mosque incident, it is worth recounting the events in greater detail. Tensions arose when government authorities demolished a mosque allegedly constructed unlawfully and issued notices of demolition to several other allegedly illegal buildings directly connected to the Red Mosque and its leadership. This stirred considerable anger in these religious circles. Under intense pressure, the government became defensive and promised to reconstruct the demolished mosque. However, the clerics at the Red Mosque in Islamabad, who run the Jamica Hafsah (a large girls madrasa) and Jami'at 'l-Ulum al-Faridiyya (a large boys madrasa), engaged in prolonged standoff with the government authorities in which both male and female students were mobilised in opposition to the government. For instance, they occupied a children's library near the Red Mosque and raided a massage parlour in the city and another private house notorious for prostitution. They demanded the government implement Sharia law across the country. As tensions grew, the government threatened to storm the Red Mosque complex and the clerics replied with a threat to launch suicide attacks throughout the country.

As the situation became critical, a group of eminent and respected ulama, including the chairman of the Wifaq al-Madaris al-Arabiyyah (Federation of the Deobandi Madrasas) and the president of the Itihad Tanzimat al-Madaris (the umbrella organisation of different madrasa federations) visited the leaders of the Red Mosque and asked them to allow the Wifaq al-Madaris to handle negotiations with the government. This proposal was, however, refused (Jalandhary, 2007). The standoff ended with "Operation Silence" in which the 
Pakistan army stormed the compound, resulting in the deaths of both male and female students. This infuriated the Taliban and their supporters. The tragic end of the standoff proved to be a beginning of large-scale violence across the country. The Red Mosque episode also exposed the fact that the Pakistani Taliban and their associates were not necessarily under the control of the akabir (the highest religious authorities).

The earlier mentioned 2006 missile strike on a madrasa in Bajaur district and the tragedy of Red Mosque in 2007 had a devastating impact for the whole country. Hitherto, the Taliban phenomenon and its actions were limited to far-flung regions. Thereafter, enraged groups of Taliban initiated a series of attacks across the country on the Pakistan army, paramilitary forces, police and other governmental institutions. In fact, the Taliban's influence became an overwhelming issue for the apparatus of the civil government in many districts near the Afghan border.

In the areas under their control, the Taliban not only tried to completely eliminate government institutions like the police, courts and schools, but they also banned a host of cultural activities and popular religious practices around religious shrines, which they considered forbidden according to their puritanical interpretation of Islam. ${ }^{6}$ A number of shrines were also attacked and damaged. These moves set off alarm bells for different religious sects, especially for Barelwis who cherish shrines and consider them to be an important element of ritual life. Also, some spiritual leaders (pirs) and ulama who dared to differ with Taliban's policy were ruthlessly killed. For instance, in September 2007, Maulana Hasan Jan, the Vice-President of the Federation of Deobandi Madrasas (Wifaq al-Madaris) was assassinated near Peshawar. In June 2008, four spiritual leaders of the Qadiri Sufi Order were assassinated in an ambush in Landi Kotal, a town in Khyber Agency, a tribal area of Pakistan.

The intra-Muslim violence and assassination of the rival religious leaders has a history in Pakistan that goes back to 1980s; that is, well before the current wave of anti-state terrorism (Jalazai, 1993). Two main rivals in this sectarian violence have been Shicis and a hard-line faction of the Deobandis. However, after the Taliban phenomenon emerged, new patterns of assassination of ulama emerged in which religious and spiritual leaders got assassinated merely for their opposition to Taliban. As a result of these incidents,

6 The Deobandi school of thought considers some of the common popular practices involving shrine ritual and worship to be unwarranted innovation in matters of religion ( bid'a). Historically, Barelwis and Deobandis have heatedly debated the status of such practices. 
many ordinary Pakistani's realised that the ambitions of some of the Taliban were not to their liking and not just about resistance to foreign forces inside Afghanistan.

Most ulama in Pakistan were of the view that both the government and Taliban militants should shun the use of force and arrive at some plausible political agreement. In October 2008, Sarfraz Ahmad Nacimi, an eminent Barelwi scholar, hosted a meeting of the Muttahidah Ulama Council (United Ulama Council) at his seminary in Lahore. Renowned ulama of virtually every religious faction attended this meeting. A joint statement was issued against suicide attacks and bomb blasts in the country, but at the same time the government was asked to stop military operations and to start a meaningful dialogue with those who had raised arms against the state (Editorial, 2008). Unfortunately, in June 2009, this very seminary became the victim of a suicide bomb blast in which Sarfraz Ahmad Nacimi was killed, apparently because of his stand against terrorism.

In spite of the above-mentioned joint statement of ulama, the Taliban onslaught continued unabated. One of the districts outside the tribal areas where the Taliban gained significant control was the Swat valley, which came to the media's attention in the beginning of 2009. The stated cause of the Taliban's campaigns in Swat was that of implementing the Sharia. Developments in Swat, however, further exposed the weakening authority of mainstream ulama over the Pakistani Taliban. This fact became discernible when Sufi Muhammad, the leader of a historically influential religious movement in Swat known as Tehrik-e-Nifaz-e-Shari'at-e-Muhammadi (TNSM), acted as mediator between the Taliban of Swat and government authorities. After the negotiations, a peace accord was signed in which the government agreed to set up Shari'a courts in that region in exchange for Sufi Muhammad's commitment to persuade the militants to disarm. It is important to bear in mind that the Taliban's commander in Swat, Fazlullah, who is still at large and believed to be in Afghanistan, is the son-in-law of Sufi Muhammad. The national parliament ratified the peace accord, but it turned out that Sufi Muhammad actually had no influence over the Taliban in Swat. Instead of disarming them, the peace accord further emboldened them and they started expanding their influence to the neighbouring districts. Eventually, the Pakistan army launched Operation Rah-e-Rast and successfully re-asserted government authority. Like in the Red Mosque episode, the pro-Taliban clerics refused to accept the authority of the central religious figures of the country. While in the case of Swat, the wellestablished local religious figure proved to be ineffective in persuading Taliban to even disarm despite his family ties to the top commander of the local Taliban. 
As the level and sphere of violence expanded, both Pakistani public opinion and the stance of the ulama toward the Taliban continued to change. ${ }^{7}$ The apparent reason for this change was that the Taliban and their associates tended to blatantly impose their understanding of religious norms on the Pakistani society. One may surmise that the public when they perceived the Taliban of Afghanistan to be a distant reality of Muslims fighting against nonMuslims had no problem with them. However, when the Talibanisation gradually become a social reality at home their narrow understanding of religion and other controversial policies generated diverse responses in a heterogeneous Pakistani society.

Arguably, the most significant re-thinking of the political situation occurred in the stance of the Barelwi ulama. In May 2009, a major Barelwi political party named, Jami'at Ulama-e-Pakistan, held its convention attended by more than 2,000 clerics, including the top religious leadership of the Barelwis in Pakistan. At this gathering, they issued a collective fatwa against suicide attacks in Pakistan and endorsed the on-going military operations in Swat. They declared that the people behind the murder of innocent civilians and desecration of holy places were acting outside the teachings of Islam. Munib al-Rahman, whose fatwa against the killing of innocent civilians has been quoted earlier, was one of the leading delegates at the convention. At this occasion, he denounced the attacks against the Pakistan army as well and did so in clear terms, a point which was missing from his 2005 fatwa (The Nation, 2009).

It is worth remembering the earlier-mentioned fatwa against Pakistani cooperation in the Us-led invasion of Afghanistan that appeared in a significant Barelwi magazine, Ziya-e-Haram, in 2001. In 2009, the same magazine lamented that certain religious parties like Jama'at-e-Islami and Jami'at 'Ulama'-e-Islam were opposing the army operation against Taliban terrorists and were thus boosting their morale and providing them the undue ethical support (Ziya-eHaram, 2009):

The al-Qaida elements in Afghanistan, from where they have also intruded into Pakistan, are Wahabis, while Taliban belong to the Deobandi faction of the Hanafijuridical school. Only the U.s. animosity had brought them together and now they are together in their enmity with the state of Pakistan and its people.

Ziya-e-Haram, 2009: $5^{2}$

7 This significant change in the public opinion has been noted regretfully in a recent proOsama bin Ladin book published from Lahore. See al-Din (2011). 
This demonstrates just how much the conditions and political environment had changed exposing the ideological, and theological fault-lines among Pakistani ulama. ${ }^{8}$ Shi'i ulama were already against Taliban for sectarian reasons. Now with increased violence in Pakistan, many Barelwi ulama and their organisations, moved away from their initial pro-Taliban stance and pitched themselves directly against two of their traditional theological rivals, namely Wahabis and Deobandis.

Perhaps the most unequivocal and detailed fatwa against the militant groups was issued by Tahir al-Qadri, a Barelwi religious leader. This extensively documented fatwa was published in a thick volume of 693 pages. It has been translated into English and widely publicised by his followers (Tahir-ulQadri, 2010a). The title of fatwa, Dihshat Gardi aur Fitna-e-Khawarij, bears an explicit polemical tone, associating the contemporary religiously-motivated militant groups with Khawarij. Apart from the title, the fatwa contains a section developing the argument that the contemporary terrorist groups are essentially descendants of Khawarij (Tahir-ul-Qadri, 2010b). The Khawarij are one of the earliest religious and political sects to rise to prominence in Islamic history. They espoused a literal and monolithic interpretation of the Qur'an and Hadith. One of their basic tenets was to declare any Muslim who committed a major sin (murtakib al-kabirah) as infidel (kafir) and therefore liable to be killed. The Khawarij were condemned as a heretical sect by both Sunni and Shici Muslims. Thus, to equate a contemporary group with the Khawarij provides a readily available sectarian frame of reference from which to condemn them.

Despite its strident tone, the fatwa was unlikely to have any impact on Taliban cadres or other religiously motivated militants in Pakistan. First, because of the polemical approach of the text. Second, because Tahir-ul-Qadri's authority as a religious scholar ('alim) has been questioned even within some Barelwi circles. His basic education and professional credentials are not religious, but

8 As the official census does not take into account affiliations with particular Muslim organisations and there is no church-like institution in Muslim societies that keep formal membership records of its adherents, it is difficult to provide exact figures for the membership of particular groups. Generally, it is estimated that around 77 per cent of the Pakistani population are Sunni Muslims, while 20 per cent are Shicis. Again, the Sunnis are divided into three main groups: Barelwis, Deobandis and Ahl-i-Hadith. Some estimates put the figure of Barelwis at about $5^{\circ}$ per cent of the total population, while Deobandis are estimated to constitute about 20 per cent. Ahl-i-Hadith, however, are a comparatively small group with approximately six per cent. For further discussion of the controversies involved in the intra-Muslim demography of Pakistan, see Sahni (2010). 
rather from modern academic institutions. Arguably, the basic purpose of this fatwa is to convince an international readership that Islam as a religion should not to be blamed for the deeds of extremist groups and to win over public opinion in Pakistan against the extremists.

\section{The Changing Stance of the Ulama}

The ulama's standpoint regarding religiously-motivated militancy in Pakistan can be divided into three stages. The first stage, which lasted from 2001 to 2004, saw Pakistani ulama unanimously supportive of the Taliban and against Pakistan's alliance with the Us. Thereafter, as the militant groups gradually expanded their sphere activities to the urban areas, public opinion started turning against them. Between 2005 and 2008, ulama from virtually all factions, including Deobandis, issued collective fatwas that denounced the terrorist attacks on civilians in Pakistan and at the same time admonished the government to stop military operations against the Taliban in tribal areas. It is important to note that the fatwas during this second phase of the violence usually evaded the question of Taliban's attacks on military targets. However, from 2009 onwards, clear differences in the standpoints of ulama came to take shape along lines defined by particular communities of interpretation. The Barelwi expressed solid support of the Pakistan army's operations against militant groups, while the stance of Deobandi and Ahl-i-Hadith ulama about the Taliban remained relatively unchanged. The Deobandis continued with the previous three-fold strategy of: (a) condemning suicide attacks on nongovernment or military targets and the consequent killings of innocent civilians; (b) pressing on the government of Pakistan to change its foreign policy and shun its cooperation with America and her North Atlantic Treaty Organisation (NATO) allies in Afghanistan; and (c) shying away from the question of militant attacks on military targets in Pakistan (Buncombe, 2008; Dash, 2008; Usman, 2006).

Since Deobandi identity refers back to the historic Dar al-'Ulum Deoband in India, it seems pertinent to refer to a statement issued by this founding seminary in the context of terrorist activities. In June 2008, the seminary issued a statement that reads: "Islam rejects all kinds of unjust violence, breach of peace, bloodshed, murder and plunder and does not allow it in any form" (Buncombe, 2008). It is, however, simply a general statement about the ethical principles of Islam. The statement does not specify any particular group that is committing violence in the name of religion. Additionally, the extremist groups do not consider their activities as "unjust violence," so they can easily 
perceive that such statements are not referring to them. Another example of this ambiguous Deobandi position in the Pakistani context is found in the stance of the leader of Jamicat Ulama-e-Islam, Maulana Fazlurahman, who said in a recent public meeting, "We cannot call the people who killed religious scholars including Maulana Hassan Jan and carried out attacks against me and other learned clerics as mujahideen" (Ali, 2011), while in the same meeting he also pressed the government to review its policy of cooperation with America in the Afghan war (ibid.). Therefore, it can be concluded that the position of the Deobandi ulama as a whole is characterised by ambivalence. They denounce the terrorist attacks inside Pakistan, but in doing so they temper their statements, as they do not want to weaken the cause of the Afghan Taliban.

\section{Conclusion}

The domestic and international political developments discussed in this article highlight the ways in which divisions between major groups of ulama have had a significant impact on the exercise of religious authority in contemporary Pakistan. It is obvious that Pakistani ulama are by no means a homogenous group. They are divided into different factions - some of which are bitterly opposed to each other on both theological and political issues. Scholars like Ashok K. Behuria argue that the seeds of distrust, which divide the country's various Sunni groups are deeply rooted and that there are multiple fault-lines between them (Behuria, 2008).

The idea of Muslim religious authority should not be taken as being either monolithic or static, even within a single country. In the case of Pakistan discussed in this article, the specific identities of partisans of particular lines of Islamic interpretations clearly play important roles in the formation of opinions about sensitive issues of interpretations of Islam in relation to contemporary politics. The Barelwi ulama, for example, do not command any significant authority among the Taliban. At the same time, social and political factors can override shared lineages of religious learning. For example, an overwhelming majority of the militant groups known as Taliban in Pakistan happen to be of Deobandi background, but a number of the fatwas issued by Deobandi ulama seem to have had little or no influence over them. Does this mean that the high-ranking Deobandi scholars have lost their religious authority and standing, being overtaken by other ulama and their militant followers? In so far as their control over the Taliban is concerned, the answer at present would appear to be yes, as they do not seem to be in control of these militant groups. If this 
conclusion is correct, then it points to a significant change and destabilisation in the patterns of socio-political and religious authority of ulama within Pakistani society.

The Taliban and other militant groups have developed their own command and control structures and organisational hierarchies, which include their own religious authorities who operate without consideration of the opinions of Deobandi scholars. However, these ulama remain relatively minor figures at present. They are not well known among the general public and have limited support among the broader Muslim population. These structures and hierarchies have generated new claims of organisational and religious authority that are parallel to the traditional mainstream Deobandi ulama. As a result, the most eminent Deobandi ulama, who are not part of a given militant group will not necessarily have authority over the militants, while a relatively low-ranking cleric placed in the command and control hierarchy of these groups may enjoy significant religious authority within these militant circles. This may indicate a decisive change in patterns of religious authority in Pakistan but only time will tell how lasting such effects will be.

\section{References}

Ahmad, Muhammad M. (2002) "Dehshat Gardi ki Tarif". Ishraq 14(3).

Alam, Arshad (2008) "The Enemy within: Madrasa and Muslim Identity in North India". Modern Asian Studies 42: 605-627.

al-Balagh (2001) "Maujudah 'Alimi Surat-e-Hal par 'Ulama'-e-Jami'ah Dar al-'Ulum Karachi (Kaurangi Town) ka Mu'aqqaf aur Appeal". al-Balagh 36(7).

al-Balagh (2005) “London Dhemakay aur Dini Madaris ka Mu’aqqif: Wifaq al-Madaris kay Akabir 'Ulama' Ka Mushtarikah Biyan (London Bombings and the Standpoint of

Religious Seminaries: A joint Statement of the 'Ulama' Belonging to the Federation of Deobandi Madaris)". al-Balagh 40(12).

al-Dayyan, Abd (2004) Wana Operation Kay Baray Main Pakistan Kay 'Ulama' Ka Muta-

fiqqa Fatwa. Islamabad: Dar al-Ifta' Markazi Lal Masjid.

al-Din, Hamid K. (ed.) (2011) But Shikan:Biyad-e-Shahid-e-Ummat. Lahore: Matbu'at-eIqaz.

al-Hasan, Manzur (2002) "Dehshat Gardi". Ishraq 14(3).

Ali, Yousaf (2011) "Killers of Scholars not Mujahideen: JuI-F Chief". The News Interna-

tional, 24 October. Available at: http://www.thenews.com.pk/Todays-News-7-74137 -Killers-of-scholars-not-mujahideen-JUI-F-chief.

al-Rahman, Munib (2005) "Qatl-i-Nahaq ka Shari Hukm". Din-e-Mubin. Available at: http://www.deenemubeen.com/2010/o3/qatl-e-na-haq/. 
Behuria, Ashok K. (2008) "Sects within Sect: the Case of Deobandi-Barelvi Encounters in Pakistan". Strategic Analysis 32.

Brown, Daniel W. (1999) Rethinking Tradition in Modern Islamic Thought. Cambridge: Cambridge University Press.

Buncombe, Andrew (2008) "Muslim Seminary Issues Fatwa Against Terrorism". The Independent, 3 October.

Crawford, Neta C. (2011) "War Related Death and Injury in Pakistan, 2004-2011", in Costs of War: Eisenhower Study Group. Rhode Island: Watson Institute for International Studies, Brown University. Available at: http://costsofwar.org/sites/default/ files/articles/16/attachments/Crawford\%2oPakistan\%2oCasualties.pdf.

Dash, Kamala K. (2008) "The Fatwa Against Terrorism: Indian Deobandis Renounce Violence but Policing Remains Unchanged". Radicalisation Crossing Borders International Conference, Melbourne, Australia, November 2008.

Editorial (2008) "Fatwa against Suicide Bombings". Daily Times, 16 October.

Haqqani, Muhammad I. al-H. I. (2005) "Maulana Sami al-Haqq Dehshat Gardi kay Ta'aqub Main”. Mahnamah al-Haqq 41(3).

Hasan, Khalid (2007) "New Lal Masjid Imam Implies Suicide Bombing Warning". Available at: http://www.dailytimes.com.pk/default.asp?page=2007/10/07/story_7 -10-2007_pg7_9 (accessed on 5 October 2013).

Iqbal, Nasir (2007) "Bodies Not Kept in I-9 Storage, sc Told”. Available at: http://dawn .com/news $/ 256353 /$ bodies-not-kept-in-i-9-storage-sc-told (accessed on 5 October 2013).

Jalandhary, Muhammad H. (2007) "Masajid ka Inhidam: Wifaq al-Madaris ka Mu’aqif”. al-Faruq 22(3).

Jalazai, Musa K. (1993) Sectarianism and Politico-Religious Terrorism in Pakistan. Lahore: Tarteeb Publishers.

Masud, Abu H. (2011) "Jihad-i-Pakistan". Available at: http://archive.org/details/ jihadepakpdf (accessed on 10 October 2013).

Metcalf, Barbara D. (1982) Islamic Revival in British India: Deoband. 1860-190o. Princeton: Princeton University Press.

Mir, Amir (2009) Talibanization of Pakistan: From 9/11 to 26/11. New Delhi: Pentagon Security International.

Rana, Muhammad A. (2009) PIPS Security Report 2008. Islamabad: Pak Institute for Peace Studies.

Rana, Muhammad A. (2010) PIPS Security Report 2009. Islamabad: Pak Institute for Peace Studies.

Rana, Muhammad A. (2011) PIPs Security Report 2010. Islamabad: Pak Institute for Peace Studies.

Rana, Muhammad A. (2013) PIPs Security Report 2012. Islamabad: Pak Institute for Peace Studies. 
Robinson, Francis (2008) "Islamic Reform and Modernities in South Asia". Modern Asian Studies 42: 259-281.

Sahni, Ajai (2010) "Pakistan," in Barry Rubin (ed.) Guide to Islamist Movements. New York: M.E. Sharpe.

Sanyal, Usha (2005) Ahmad Riza Khan Barelwi: In the path of the Prophet. Oxford: One World Publications.

Tahir-ul-Qadri, Muhammad (2010a) Dihshat Gardi aur Fitna-e-Khawarij. Lahore: Minhaj al-Qur'an.

Tahir-ul-Qadri, Muhammad (2010b) Fatwa on Suicide Bombings and Terrorism. London: Minhaj Publications.

The Nation (2009) "Ulema Issue Fatwa against Suicide Attacks". The Nation, 18 May. Available at: http://www.nation.com.pk/pakistan-news-newspaper-daily-english -online/politics/18-May-20og/Ulema-issue-fatwa-against-suicide-attacks (accessed on 21 November 2012).

Usman, Abd al-K. (2006) "Fida’i Hamlay: Islami Taclimat ki Raushni main Tahqiqi Jaizah". M.Phil. dissertation, Bhahu-Din Zakariya University Multan.

Usmani, Muhammad T. (2001) "Shiddat Pasandi aur Dehshat Gardi". al-Balagh 36(9).

Zaman, Muhammad Q. (2002) The Ulama in Contemporary Islam:Custodians ofChange. Princeton: Princeton University Press.

Zaman, Muhammad Q. (2012) Modern Islamic Thought in a Radical Age-Religious Authority and Internal Criticism. Cambridge: Cambridge University Press.

Ziya-e-Haram (2001) "Fatwa-e-'Ulama dar Ta'id-e-Afghanistan". Ziya-e-Haram 32(3).

Ziya-e-Haram (2009) "Pakistan main Phaylti Hu’i Jang: Palisiyun par Nazr-e-Sani ki Ja’y”. Ziya-e-Haram 40(2). 